特集 これからのプライマリ•ケアを切り拓く人とことば 第六景 病院総合医の役割 1 : 診療（総合外来と総合病棟）

\title{
To be a generalist from a specialist
}

\section{専門医から総合医へ}

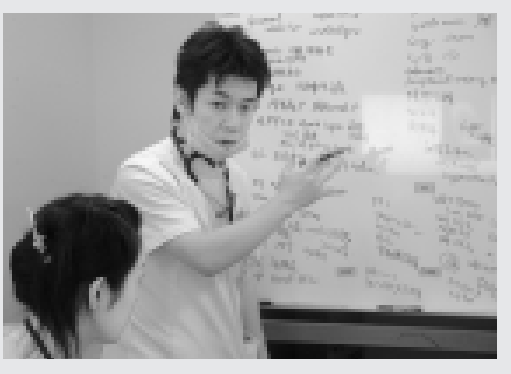

1993 年札棍医科大学卒業 脳神経外 科医としてストレート研修を開始する。 1999 年脳神経外科専門医取得するが, 2003 年ジェネラリストを目指して札棍 医科大学地域医療総合医学講座所属とな り，2004 年より北海道勤医協中央病院総 合診療部所属となる. 2008 年から同院 総合診療部部長となり, 初期研修医・後 期研修医の教育も担当している.

認定資格 日本家庭医療学会家庭医療指 導医 日本内科学会認定内科医 日本脳 神経外科学会脳神経外科専門医 医学博 士

良質な家庭医・総合医育成のための理 想的な病棟研修を提供するために日々努 力しており，多くの初期研修医・後期研 修医が研修している．北海道プライマリ ケアネットワーク「ニポポ」・北海道家庭 医療学センターの後期研修プログラムの 病棟研修先としても選ばれている.

\section{臺野 巧}

安全で質の高い医療を提供し，かつ患者満足度を上げるためには，家 庭医・総合医（ジェネラリスト）の数を増やすことが必要である。しか しながら，ジェネラリストを目指す新卒医師の割合はまだ高いとは言え ない ${ }^{1}$. 日本家庭医療学会が 2007 年から学会認定の後期研修プログラ ムを立ち上げたが, 新医師臨床研修制度下で初期研修を終えている医師 が対象となっている。一方，旧制度下のもとでストレート研修を行った 世代の中にもジェネラリストに親和性のある医師は存在するが，専門医 からジェネラリストへの道は一定のルートがあるわけではないので容易 とはいえない.

筆者の所属する北海道勤医協中央病院総合診療部では, 専門医から総 合医を目指す医師の再トレーニングを以前から行っている．筆者自身も 脳神経外科医を辞めて, 2004 年にここで研修を開始し, 現在もジェネラ リストとして診療にあたっている. 2007 年からは当総合診療部の責任 者として，今度は逆に総合医を目指す医師のサポートを行っている。 こ の間にも, 麻酔科・整形外科・小児科・基礎研究者から総合医を目指す 医師がわれわれの施設で研修している．ジェネラリストを育成するため には，実際にジェネラリストとして診療している指導医のもとでトレー ニングすることが重要で, 各専門科をローテーションするだけでは不十 分である. 当院では, 1 年間総合診療病棟で研修を行った後に, さらに 1 年で各専門分野の研修を行うという 2 年間のプログラムを提供してい る.

\section{文 献}

1）宮田靖志，他. 地域医療に従事するプライマリ・ケア医を育成するための 卒前医学教育. プライマリ・ケア. 2009, Vol. 32, No.4, p. 230-241 